V. T. MARCHENKO ${ }^{1}$, N. P. SAZYNA ${ }^{1}$, P. P. KHOROLSKYI ${ }^{1}$, A. A. VOZNENKO ${ }^{2}$

\title{
ECONOMETRIC MODEL FOR CALCULATING THE EXPECTED COST OF NEW ROCKET HARDWARE DEVELOPMENT WITH ACCOUNT FOR UNCERTAINTY FACTORS
}

\author{
${ }^{I}$ Institute of Technical Mechanics \\ of the National Academy of Sciences of Ukraine and the State Space Agency of Ukraine \\ 15 Leshko-Popel St., 49005,Dnipro, Ukraine; e-mail: office.itm@nas.gov.ua \\ ${ }^{2}$ Ministry of Finance of Ukraine \\ , 12/2 Hrushevsky St., 01008, Kyiv,Ukraine; e-mail:infomf@minfin.gov.ua
}

Rocket hardware represents technically complex expensive and unique engineering systems. At present, decisions on the advisability of implementation of new pocket hardware development projects are made based on financial feasibility study materials with the use of the benefit-cost or cost-efficiency criterion without even rough quantitative estimates of cost overrun or efficiency reduction risks.

The methodological approach presented in this paper is a first stage in the development of mathematical methods and algorithms for calculating the expected engineering and economical performance characteristics of new rocket hardware development projects with account for risks.

This paper proposes an econometric model for calculating the expected cost of new rocket hardware development and assessing the risk of cost overrun and delay in the development work.

The mathematical model is based on an analytical relationship between the required performance characteristics of a new rocket product and its cost parameters.

To make the expected cost calculation and cost overrun risk assessment method more formal, the technical structure of a rocket system is represented as a weighted directed tree graph. The graph vertices are the rocket system itself (the root vertex) and its components. The graph arc weights are sequence of the engineering and economical performance characteristics of the lower-level component included in the nearest vertex of the tree graph.

The risk of expected cost overrun and delay in the development work is due to uncertainty in the input data used in the calculation (the variables and the parameters of the econometric model). The data uncertainty is modeled using the fuzzy set theory: the model variables and parameters are represented as fuzzy triangular numbers.

Keymords expected cost, feasibility study, space systems.

1. Alpatov .P., Marchenko V. T., Sazina N. P., Khololsky орольский P. P. Methodological approach to technical and economic feasibility of projects for new space technology products (in Russian). Tekhnicheskaya Mekhanika, 2015. No, 3. Pp..3-17.

2. Pylypenko O. V., Pereverzev E. S., Alpatov A. P., Marchenko V. T., Pechenevskaya O. K., Khorolskui P. P. Efficiency of Scientific and Technical Projects and Programs (in Russian). Dnipropetrovsk: Porogi, 2008. 509 pp.

3. Dubois D., Prade H. Possibility Theory: Applications to Knowledge Representation in Data Processing (in Russian). Moscow: Radio I Svyaz, 1990.

4. Marchenko V. T., Sazina N. P., Syutkina-Doronina S. V. On the method of simulation of uncertainties of technical and economical data for problems of evaluation of research projects (in Russian). Tekhnicheskaya Mekhanika. 2016. No. 2. Pp.. 137-146. 